\title{
Cancer Influences the Elemental Composition of the Myocardium More Strongly than Conjugated Linoleic Acids-Chemometric Approach to Cardio-Oncological Studies
}

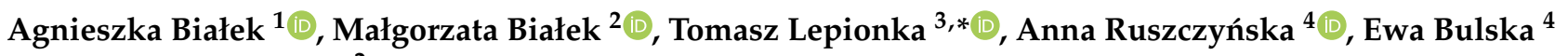 \\ and Marian Czauderna ${ }^{2}$ \\ 1 Department of Biotechnology and Nutrigenomics, Institute of Genetics and Animal Biotechnology of the \\ Polish Academy of Sciences, Postępu 36A Jastrzębiec, 05-552 Magdalenka, Poland; a.bialek@igbzpan.pl \\ 2 Department of Animal Nutrition, The Kielanowski Institute of Animal Physiology and Nutrition, \\ Polish Academy of Sciences, Instytucka 3, 05-110 Jabłonna, Poland; m.bialek@ifzz.pl (M.B.); \\ mr.czauderna@gmail.com (M.C.) \\ 3 Department of Bioaerosols, The Biological Threats Identification and Countermeasure Center of the General \\ Karol Kaczkowski Military Institute of Hygiene and Epidemiology, Lubelska 4 St, 24-100 Puławy, Poland \\ 4 Biological and Chemical Research Centre, Faculty of Chemistry, University of Warsaw, Żwirki i Wigury 101, \\ 02-089 Warsaw, Poland; aruszcz@chem.uw.edu.pl (A.R.); ebulska@chem.uw.edu.pl (E.B.) \\ * Correspondence: tomasz.lepionka@wihe.pl; Tel.: +48-261-519-812
}

check for updates

Citation: Białek, A.; Białek, M.; Lepionka, T.; Ruszczyńska, A.; Bulska, E.; Czauderna, M. Cancer Influences the Elemental Composition of the Myocardium More Strongly than Conjugated Linoleic AcidsChemometric Approach to Cardio-Oncological Studies. Molecules 2021, 26, 7127. https://doi.org/ $10.3390 /$ molecules 26237127

Academic Editor: Daniel Cozzolino

Received: 14 October 2021

Accepted: 23 November 2021

Published: 25 November 2021

Publisher's Note: MDPI stays neutral with regard to jurisdictional claims in published maps and institutional affiliations.

Copyright: (c) 2021 by the authors. Licensee MDPI, Basel, Switzerland. This article is an open access article distributed under the terms and conditions of the Creative Commons Attribution (CC BY) license (https:// creativecommons.org/licenses/by/ $4.0 /)$
Abstract: The aim of the study was to verify in a cardio-oncological model experiment if conjugated linoleic acids (CLA) fed to rats with mammary tumors affect the content of selected macro- and microelements in their myocardium. The diet of Sprague-Dawley females was supplemented either with CLA isomers or with safflower oil. In hearts of rats suffering from breast cancer, selected elements were analyzed with a quadrupole mass spectrometer with inductively coupled plasma ionization (ICP-MS). In order to better understand the data trends, cluster analysis, principal component analysis and linear discriminant analysis were applied. Mammary tumors influenced macro- and microelements content in the myocardium to a greater extent than applied diet supplementation. Significant influences of diet $(p=0.0192)$, mammary tumors $(p=0.0200)$ and interactions of both factors ( $p=0.0151$ ) were documented in terms of Fe content. CLA significantly decreased the contents of $\mathrm{Cu}$ and $\mathrm{Mn}$ ( $p=0.0158$ and $p=0.0265$, respectively). The level of Ni was significantly higher $(p=0.0073)$, which was more pronounced in groups supplemented with CLA. The obtained results confirmed antioxidant properties of CLA and the relationship with Se deposition. Chemometric techniques distinctly showed that the coexisting pathological process induced differences to the greater extent than diet supplementation in the elemental content in the myocardium, which may impinge on cardiac tissue's susceptibility to injuries.

Keywords: chemometry; conjugated linoleic acid; breast cancer; heart; cardio-oncology

\section{Introduction}

Noncommunicable diseases (NCDs), also known as chronic diseases, include cardiovascular diseases (CVD), cancers, chronic respiratory diseases and diabetes. They are the result of combination of genetic, physiological, environmental and behavioral factors [1]. CVD are the most common NCDs globally, responsible for an estimated 17.8 million deaths in 2017 [2], whereas cancer is a leading cause of death worldwide, accounting for an estimated 9.6 million deaths in 2018 [3]. Numerous authorities emphasize that CVD and cancer share the same risk factors, including tobacco smoking, physical inactivity, nutritional mistakes, alcohol consumption, obesity, hypertension and hyperlipidemia [4]. This evidence coupled with the fact that cardiotoxicity has become the main cause of morbidity and mortality of cancer survivors gave rise to the new "cardio-oncology" or "onco-cardiology" concept [5]. It includes early recognition, mitigation and prevention 
of the effects of cancer and its treatment on the cardiovascular system as well as the care of cancer patients with cardiovascular disease, overt or occult and already established or acquired during treatment.

Elements, together with water and other nutrients (proteins, fats, carbohydrates and vitamins) are considered crucial for human and animal life. Essential mineral elements include macroelements ( $\mathrm{Na}, \mathrm{Mg}, \mathrm{K}$ and $\mathrm{Ca}$ ), which constitute about $1.89 \%$, while the rest is made up of 11 typical trace elements, which play key roles in metabolism from the lowest level of intracellular life to the functional activity of the largest organs and exert immense influence on all body functions organs. The composition of macro- and trace elements in body fluids and tissues is influenced by sex and age, dietary intake, uptake in the gastrointestinal tract, storage, excretion, physical condition and the presence or absence of disease state, as well as immune system disorders [6,7].

Both CVDs and cancer are the cause of disturbances in macro- and trace elements' homeostasis in numerous tissues and organs. For example, in physiological conditions, myocardial mitochondria control the intracellular concentration of $\mathrm{Ca}$ ions, and pathologic changes in Ca homeostasis can initiate deleterious events leading to ischemic myocardial injury and cell death. The deposition of Ca salts into myocardial cells (dystrophic calcification) serves as a marker for heart muscle cell damage [8]. The morbid growth of mineral deposits in human heart valves (calcification) can lead to loss of their functionality and, thus, is the first reason for valve replacement and the third leading cause of CVD [9]. It was also established that trace elements, in particular $\mathrm{Fe}, \mathrm{Cu}, \mathrm{Zn}, \mathrm{Mn}$ and Se, can affect the course of arterial hypertension and myocardial infarction [10]. Several elements (Se, Cr, $\mathrm{Cu}, \mathrm{Mg}, \mathrm{Zn}, \mathrm{Li}$ and $\mathrm{V}$ ) are suspected of being involved in the genesis of arteriosclerotic heart disease [11]. $\mathrm{Cu}$ and $\mathrm{Fe}$ are involved in many aspects of energy metabolism and are important in the synthesis of hemoglobin, myoglobin and cytochromes [12]. Se deficiency disturbs the optimal functioning of several cellular mechanisms and may promote the development of atherosclerosis [13]. Low Se concentration is also a risk factor for arterial hypertension and myocardial infarction, and a factor aggravating symptoms of myocardial ischemia [10]. Some trace elements modulate functions of cellular pro- and antioxidant systems [10], e.g., $\mathrm{Cu}, \mathrm{Zn}$ and $\mathrm{Mn}$ protect against the effects of increased free reactive oxygen species via $\mathrm{Cu}-\mathrm{Zn}$ superoxide dismutase and $\mathrm{Mn}$ superoxide dismutase [12]. This is of great importance, as the heart is prone to oxidative damage as it has lower activity of antioxidant enzymes (e.g., superoxide dismutase) than other tissues (e.g., liver) [14]. It was established that patients with heart failure have increased oxidative stress, which also causes a deficiency of Fe, Se and $\mathrm{Zn}$ [15]. Intensive production of reactive oxygen metabolites and activation of lipid peroxidation are the main mechanisms underlying myocardial damages [10] and increased lipid peroxidation in the myocardium is related to significant decrease in the heart content of Se, Mn and $\mathrm{Cr}$ [16]. Additionally, certain heavy metals (e.g., $\mathrm{Cd}, \mathrm{Co}, \mathrm{Pb}$ and $\mathrm{Hg}$ ) can exert cardiotoxic effect due to, at least in part, increased vulnerability of the heart to free oxygen radicals [17].

Abnormalities in trace elements could severely impair an organism's resistance against carcinogenic stress and induce carcinogenicity [18]. Trace elements may directly or indirectly affect the carcinogenic process, including tumor growth, replication, invasion and metastasis [19]. Some meta-analyses revealed that trace elements disturbances (Fe or Se deficiency) play an important role in carcinogenesis of breast tissue [20]. Taking into account that chemotherapy with adriamycin and cytoxan can significantly increase oxidative stress and decrease total antioxidant capacity in women with breast cancer [21], it may also influence elements content, especially those of antioxidant properties. It was noticed that elevated levels of $\mathrm{Ca}, \mathrm{Cr}, \mathrm{Cu}, \mathrm{Fe}$ and $\mathrm{Sr}$ in breast cancer patients decreased and returned to the normal range after the chemotherapy. The opposite situation was observed for $\mathrm{Ti}, \mathrm{Zn}$ and Se, as their levels restored to near normal range after chemotherapy [22]. On the one hand, metals and metal compounds are an important risk factor for the development of breast cancer, while on the other hand, they might have also beneficial effects, inducing apoptosis and cytotoxicity, in breast cancer cells [23]. Hence, knowledge about 
the imbalance of trace elements in biological samples of cancer patients might be helpful to elicit a unique possibility of identifying novel anti-tumor drugs based on the elements of significance [22].

Conjugated linoleic acid (CLA) isomers are a group of conjugated fatty acids (CFA) of multiple biological activities. They are positional and geometric isomers of linoleic acid ( 9912 C18:2) naturally present in different dietary sources of animal origin, especially meat and dairy products [24]. CLA isomers were established as potent anticancerogenic agents in a breast cancer model. Searching for the mechanisms of their action, they were found as forceful indicators of numerous metabolic changes in both physiological and pathological conditions, which may affect breast cancer risk [25-31]. These changes concerned the whole body, including the cardiac tissue. It was previously demonstrated that both diet supplementation with CLA isomers and coexisting cancerous process can influence the fatty acids profile and lipid peroxidation in cardiac tissue of female rats suffering from breast cancer [32]. Cancerous process intensified the lipid peroxidation (as confirmed by the elevated levels of 7-ketocholesterol in the hearts), while CLA isomers applied with the diet significantly inhibited polyunsaturated fatty acids (PUFA) oxidation (as evidenced by the lower content of malondialdehyde (MDA)). Taking into account that both dietary factors and cancerous process may influence macro- and trace elements content in the body (also in cardiac tissue), in the present study, a cardio-oncological approach is proposed for searching for other proposed mechanisms of CLA action. We hypothesized that dietary CLA isomers administrated to animals with mammary tumors may affect the elements composition in their hearts. The main aim of present study was to verify our hypothesis by evaluation of the influence of a commercial dietary supplement containing CLA isomers on the content of selected macro- and microelements in the hearts of female rats with chemically induced mammary tumors. Moreover, some correlations among investigated elements and fatty acids content, expressed by the indices related to CVD risk and lipid peroxidation markers, were investigated by using a chemometric approach.

\section{Results}

A detailed daily dietary intake of macro- and microelements is presented in Table 1. Their consumption as well as the consumption of other compounds was estimated based on the composition of ingredients of rats' diets, assuming that $10 \mathrm{~g}$ of laboratory fodder and $0.15 \mathrm{ml}$ of dietary supplement was ingested daily by a single rat. In Labofeed $\mathrm{H}$, the most abundant macroelements were $\mathrm{K}, \mathrm{Ca}, \mathrm{Mg}$ and $\mathrm{Na}$, which make them predominant in diets of experimental animals. In dietary supplements levels of elements were lower as compared to laboratory fodder: in $\mathrm{SAF}$ oil $\mathrm{B}, \mathrm{Al}$ and $\mathrm{Ca}$ were detected in the highest amounts, whereas in Bio-C.L.A., only $\mathrm{Ca}, \mathrm{Ba}, \mathrm{Cr}, \mathrm{Pb}$ and $\mathrm{Sr}$ were detected, as other elements were below the limit of detection (LOD). Diet modification with SAF oil or CLA supplement did not influence the mean dietary intake of investigated elements in all experimental groups (Table 1).

Table 1. Daily intake of dietary ingredients.

\begin{tabular}{|c|c|c|}
\hline & \multicolumn{2}{|c|}{ Diet } \\
\hline & SAF/SAFplus & CLA/CLAplus \\
\hline \multicolumn{3}{|l|}{ Elements: } \\
\hline K [mg] & $<186$ & $<186$ \\
\hline $\mathrm{Mg}[\mathrm{mg}]$ & $<29.3$ & $<29.3$ \\
\hline $\mathrm{Na}[\mathrm{mg}]$ & $<24.2$ & $<24.2$ \\
\hline $\mathrm{Ca}[\mathrm{mg}]$ & 76.9 & 76.9 \\
\hline $\mathrm{Fe}[\mathrm{mg}]$ & $<2.27$ & $<2.27$ \\
\hline $\mathrm{Zn}[\mathrm{mg}]$ & $<0.34$ & $<0.34$ \\
\hline $\mathrm{Cu}[\mathrm{mg}]$ & $<0.10$ & 0.10 \\
\hline $\mathrm{Mn}[\mathrm{mg}]$ & 0.43 & $<0.43$ \\
\hline Se $[\mu \mathrm{g}]$ & 1.65 & $<1.65$ \\
\hline Co $[\mu \mathrm{g}]$ & 2.25 & 2.25 \\
\hline
\end{tabular}


Table 1. Cont.

\begin{tabular}{|c|c|c|}
\hline & \multicolumn{2}{|c|}{ Diet } \\
\hline & SAF/SAFplus & CLA/CLAplus \\
\hline $\mathrm{Cr}[\mu \mathrm{g}]$ & 3.00 & 2.99 \\
\hline $\mathrm{Ni}[\mu \mathrm{g}]$ & 10.2 & 10.2 \\
\hline $\mathrm{Al}[\mathrm{mg}]$ & 1.52 & $<1.51$ \\
\hline Sr [mg] & 0.11 & 0.11 \\
\hline $\mathrm{Ba}[\mu \mathrm{g}]$ & 53.7 & 53.6 \\
\hline $\mathrm{Pb}[\mu \mathrm{g}]$ & 1.78 & 1.78 \\
\hline \multicolumn{3}{|l|}{ Fatty acids: } \\
\hline $\mathrm{C} 6: 0[\mu \mathrm{g}]$ & 104 & 104 \\
\hline $\mathrm{C} 8: 0[\mathrm{mg}]$ & 0.00 & 0.17 \\
\hline $\mathrm{C} 10: 0[\mu \mathrm{g}]$ & 0.00 & 127 \\
\hline $\mathrm{C} 12: 0[\mu \mathrm{g}]$ & 48.0 & 52.0 \\
\hline $\mathrm{C} 14: 0[\mu \mathrm{g}]$ & 215 & 215 \\
\hline $\mathrm{C} 15: 0[\mu \mathrm{g}]$ & 107 & 100 \\
\hline $\mathrm{C} 16: 0[\mathrm{mg}]$ & 12.4 & 12.7 \\
\hline$c 7 \mathrm{C} 16: 1[\mu \mathrm{g}]$ & 142 & 123 \\
\hline 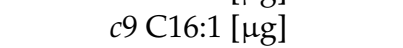 & 201 & 196 \\
\hline $\mathrm{C} 17: 0[\mu \mathrm{g}]$ & 108 & 111 \\
\hline c6 C17:1 [ $\mu \mathrm{g}]$ & 62.0 & 62.0 \\
\hline c9 C17:1 [ $\mu \mathrm{g}]$ & 9.52 & 7.48 \\
\hline $\mathrm{C} 18: 0[\mathrm{mg}]$ & 4.40 & 5.29 \\
\hline$t 11 \mathrm{C} 18: 1[\mu \mathrm{g}]$ & 0.00 & 7.37 \\
\hline$c 9$ C18:1 [mg] & 29.1 & 16.3 \\
\hline c11 C18:1 [mg] & 0.69 & 0.77 \\
\hline 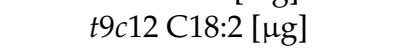 & 0.00 & 27.9 \\
\hline c9c12 C18:2 [mg] & 51.6 & 47.1 \\
\hline c9c12c15 C18:3 [mg] & 22.2 & 22.1 \\
\hline $\mathrm{C} 20: 0[\mu \mathrm{g}]$ & 237 & 218 \\
\hline c9t11 C18:2 [mg] & 0.00 & 13.7 \\
\hline$t 7 c 9 \mathrm{C} 18: 2[\mu \mathrm{g}]$ & 0.00 & 130 \\
\hline t10c12 C18:2 [mg] & 0.00 & 13.5 \\
\hline c11c13 C18:2 [mg/g] & 0.00 & 0.57 \\
\hline$c 9 c 11 \mathrm{C} 18: 2[\mu \mathrm{g}]$ & 0.00 & 96.5 \\
\hline c11 C20:1 [mg] & 189 & 104 \\
\hline$c 8 c 11 c 14 c 17 \mathrm{C} 20: 4[\mu \mathrm{g}]$ & 92.7 & 0.00 \\
\hline $\mathrm{C} 22: 0[\mu \mathrm{g}]$ & 54.0 & 104 \\
\hline $\mathrm{C} 24: 0[\mu \mathrm{g}]$ & 27.9 & 8.96 \\
\hline$c 15 \mathrm{C} 24: 1[\mu \mathrm{g}]$ & 33.1 & 25.8 \\
\hline \multicolumn{3}{|l|}{$\begin{array}{l}\text { Conjugated fatty acids: } \\
{[\mathrm{mg} / \mathrm{g}]}\end{array}$} \\
\hline$\Sigma$ CFA: & 0.07 & 26.5 \\
\hline$\Sigma \mathrm{CD}:$ & 0.03 & 26.1 \\
\hline$t t \mathrm{CD}$ & 0.02 & 0.71 \\
\hline$c t / t c \mathrm{CD}$ & 0.01 & 24.6 \\
\hline$c c \mathrm{CD}$ & 0.00 & 0.86 \\
\hline$\Sigma \mathrm{CT}:$ & 0.04 & 0.41 \\
\hline$t t t \mathrm{CT}$ & 0.03 & 0.38 \\
\hline ttc CT & 0.00 & 0.03 \\
\hline $\operatorname{cct} \mathrm{CT}$ & 0.00 & 0.00 \\
\hline Cholesterol $[\mu \mathrm{g}]$ & 1550 & 1550 \\
\hline \multicolumn{3}{|l|}{ Tocopherols: $[\mu \mathrm{g}]$} \\
\hline$\delta$ (delta) tocopherol & 278 & 281 \\
\hline$\gamma($ gamma) tocopherol & 46.9 & 47.2 \\
\hline$\alpha$ (alpha) tocopherol & 150 & 173 \\
\hline$\alpha$ (alpha) tocopherol acetate & 842 & 831 \\
\hline
\end{tabular}

CFA—conjugated fatty acids, CD—conjugated dienes, CT-conjugated trienes, $c c-c i s, c i s$ isomers, $c t / t c$ — cis, trans/trans, cis isomers, $t$ - -trans, trans isomers, $t t$ - trans, trans, trans isomers, ttc — trans, trans, cis isomers, cct-cis, cis, trans isomers. 
There were no spontaneous tumors during the experiment in groups not subjected to DMBA treatment. A single dose of intragastrically administrated DMBA was efficient in the induction of mammary tumors, identified as adenocarcinomas and papillary adenocarcinomas of the mammary gland. Detailed results concerning cancer incidence were presented previously [32].

The content of macroelements in cardiac tissue were affected by the presence of mammary tumors to a greater extent than by the animals' diet (Table 2). This influence was observed for $\mathrm{K}, \mathrm{Mg}$ and $\mathrm{Na}$ levels. As the same minerals are concerned, significant interactions of both experimental factors were observed simultaneously with a significant impact of tumors occurrence.

Table 2. Content of macro- and microelements in hearts of female rats supplemented with safflower oil (SAF oil) or Bio-C.L.A.

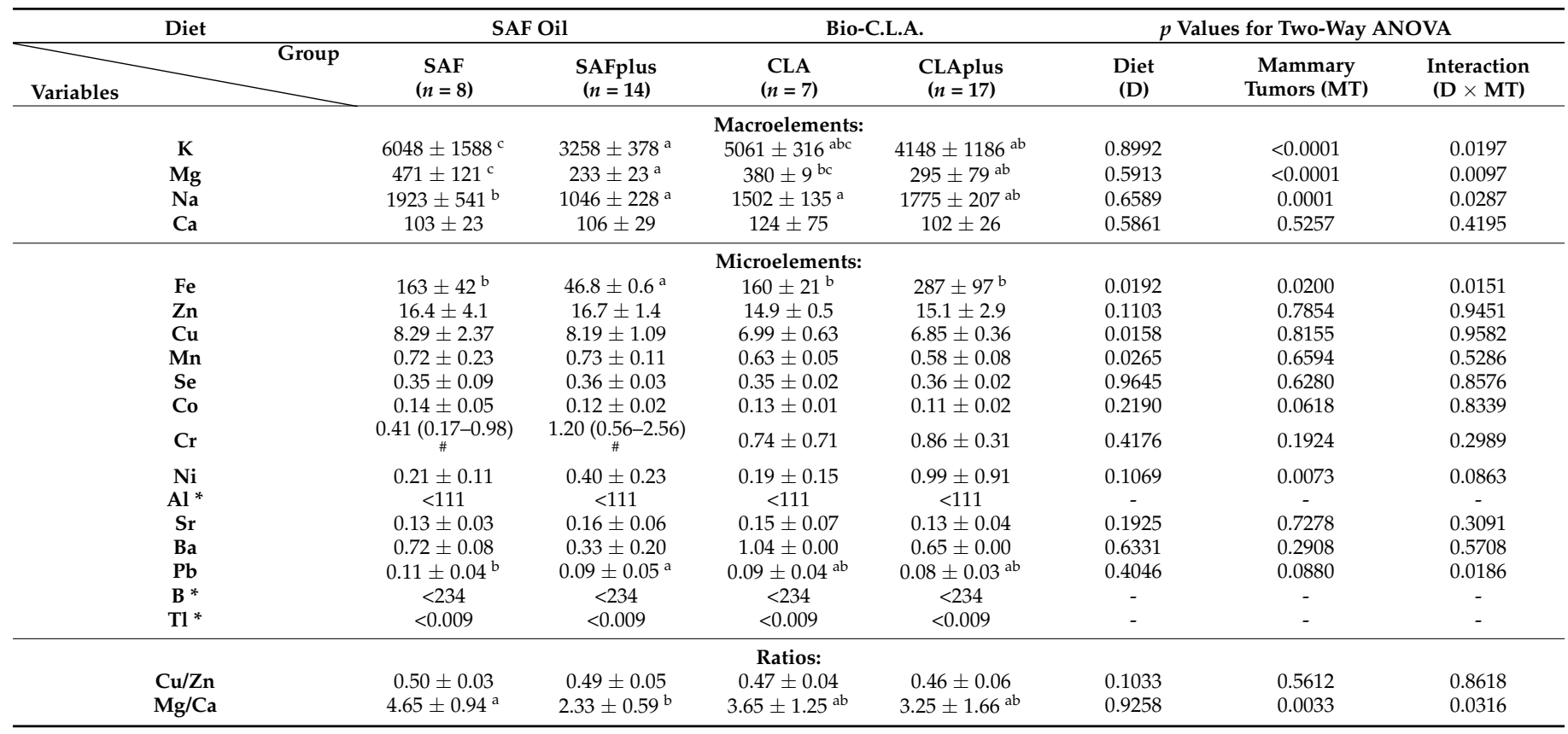

* content was below the limit of detection (LOD): $111 \mathrm{mg} / \mathrm{kg}$ for Al, $234 \mathrm{mg} / \mathrm{kg}$ for B and $0.009 \mathrm{mg} / \mathrm{kg}$ for Tl; data are shown as mean values \pm standard deviation (SD). Variables with skew distribution were transformed into logarithms, retransformed after calculations and presented as mean and confidence interval and marked with ${ }^{\#}$. $p$ value $\leq 0.05$ - significant differences among groups in two-way ANOVA. 0.00-amount was below the quantification limit (<LOQ). D—diet; MT—mammary tumors, D $\times$ MT-interaction; when interaction $(\mathrm{D} \times \mathrm{MT})$ occurs, the significance of differences among groups was further analyzed by post hoc HSD Tukey test or multiple comparison tests. abc-values with different superscripts in rows significantly differ at $p$ value $\leq 0.05$. SAF group-animals receiving safflower oil; SAFplus group —animals receiving safflower oil treated with DMBA; CLA group-group of animals receiving Bio-C.L.A.; CLAplus group - group of animals receiving Bio-C.L.A. treated with DMBA.

Microelements contents in the rats' hearts were only slightly influenced by the applied experimental factors (Table 2$)$. Significant influences of diet $(p=0.0192)$, mammary tumors presence $(p=0.0200)$ and interactions of both examined factors $(p=0.0151)$ were documented in terms of Fe content in the hearts of rats. Supplementation of diet with CLA isomers also caused a significant decrease in the contents of Cu and Mn ( $p=0.0158$ and $p=0.0265$, respectively) in cardiac tissue. The level of $\mathrm{Ni}$ in cardiac tissue of rats with mammary tumors was significantly higher $(p=0.0073)$, which was more pronounced in groups supplemented with Bio-C.L.A., where this increase was over fivefold. Among microelements, contents of $\mathrm{Al}$ and $\mathrm{B}$ and $\mathrm{Tl}$ were lower than the LOD (Table 2). The interaction of both examined factors also significantly influenced the quantity of the toxic heavy metal $(\mathrm{Pb})(p=0.0186)$, which was decreased synergistically by diet modification and mammary tumors presence.

The $\mathrm{Cu} / \mathrm{Zn}$ ratio was similar in all experimental groups and influenced neither investigated factors nor their interaction. The $\mathrm{Mg} / \mathrm{Ca}$ ratio was the highest in SAF, whereas its lowest level was established in SAFplus. Significant differences were observed between 
these two groups. Both MT and D $\times$ MT influenced Mg/Ca values $(p=0.033$ and $p=0.0186$, respectively) (Table 2).

Despite similar daily intake of examined macro- and microelements of all groups, the chemometric approach applied in present study appeared as an objective strategy for evaluation and data interpretation of dissimilarities in mineral content in myocardium samples of experimental dietary groups, especially taking into account the coexisting pathological process that manifested as mammary tumor appearances. Different multivariate analyses were verified to represent a powerful method for distinguishing experimental groups on the basis of all of the existing dependencies.

Similarity analysis, performed by the grouping of features and objects confirmed that both applied diet supplementation and the coexisting pathological process influence the mineral status of myocardium (Figure 1). SAFplus animals were characterized by a low content of $\mathrm{Fe}, \mathrm{Pb}, \mathrm{K}, \mathrm{Mg}$, $\mathrm{Na}$ and $\mathrm{Ba}$ and a high content of $\mathrm{Cu}, \mathrm{Mn}, \mathrm{Zn}, \mathrm{Cr}$ Se and $\mathrm{Sr}$. Unlike them, in cardiac tissue of rats receiving safflower oil, which were not subjected to DMBA treatment, high levels of $\mathrm{Fe}, \mathrm{Pb}, \mathrm{K}, \mathrm{Mg}, \mathrm{Na}$ and $\mathrm{Ba}$, as well as $\mathrm{Co}$, were observed. In myocardium of CLA-supplemented rats suffering from breast tumors, low levels of most of the examined minerals were detected. Only $\mathrm{Fe}, \mathrm{Pb}$, Se and $\mathrm{Ni}$ were present in high amounts. The CLA group without DMBA administration was characterized by a high content of $\mathrm{Ca}$ and low levels of $\mathrm{Se}$ and $\mathrm{Ni}$, in comparison to the CLAplus group.

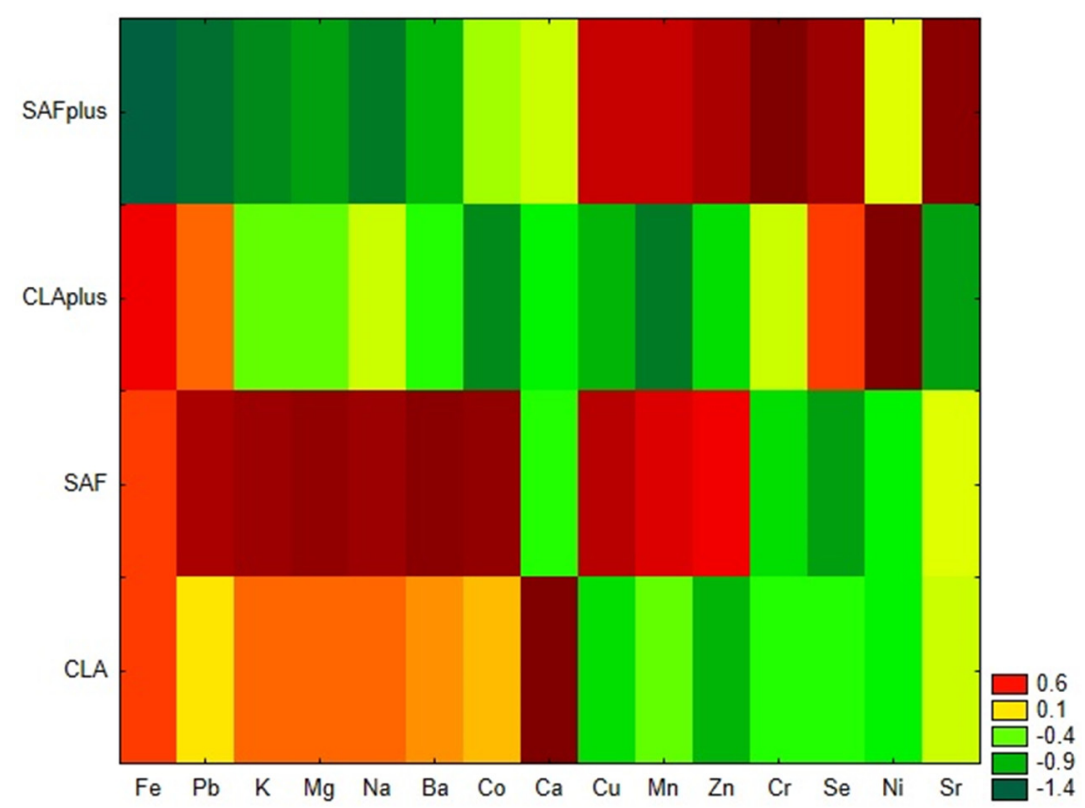

Figure 1. Heat maps of macro- and microelements content in the myocardium of experimental groups. SAF group—animals receiving safflower oil; SAFplus group—animals receiving safflower oil treated with DMBA; CLA group—group of animals receiving Bio-C.L.A.; CLAplus group—group of animals receiving Bio-C.L.A. treated with DMBA.

The results of CA are presented as dendrograms in Figure 2a,b. The application Sneath's criterion (33\%) to the dendrogram analysis allowed us to distinguish four clusters (S1-S4) that group the examined minerals (Figure 2a). The first cluster (S1) included $\mathrm{Co}, \mathrm{Cu}$, $\mathrm{Mn}$, Se and $\mathrm{Zn}$, whereas $\mathrm{Cr}, \mathrm{Ni}$ and Se were incorporated into the second cluster (S2). Ba, $\mathrm{Ca}, \mathrm{Pb}$ and $\mathrm{Sr}$ created the third cluster and $\mathrm{Fe}, \mathrm{K}, \mathrm{Mg}$ and $\mathrm{Na}$ were included in the fourth cluster (S4). A dendrogram of the similarities in mineral content in myocardium samples revealed four clusters (S1-S4) due to the application of a more rigorous Sneath's criterion (33\%) (Figure 2b), but the samples' allocation to distinguished clusters only coincided to a small extent with the experimental dietary groups. 


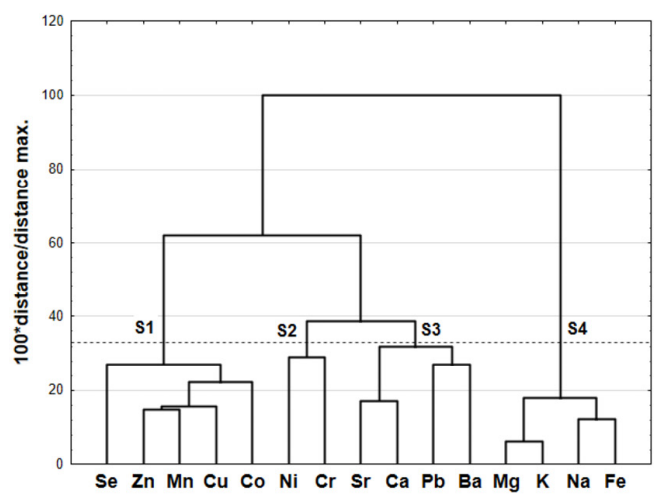

(a)

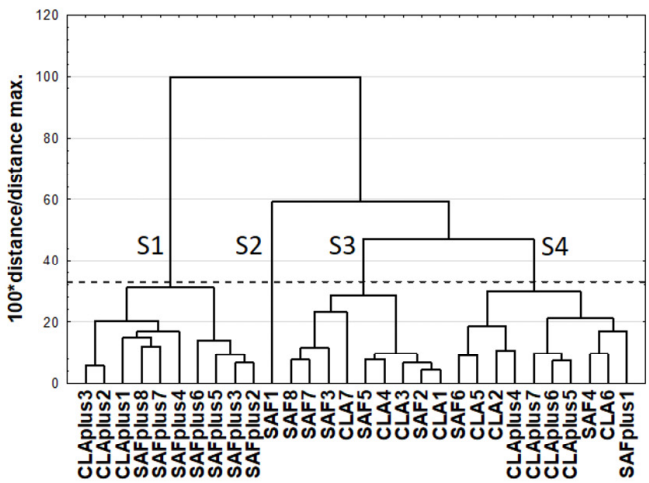

(b)

Figure 2. (a) Dendrogram of similarities of minerals and (b) their content in the myocardium of experimental groups. SAF group - animals receiving safflower oil; SAFplus group-animals receiving safflower oil treated with DMBA; CLA group—group of animals receiving Bio-C.L.A.; CLAplus group—group of animals receiving Bio-C.L.A. treated with DMBA.

PCA analysis identified four factors carrying $80.9 \%$ of the total variability. The detailed matrix of factor analysis structure with the factor load values is presented in Table 3. The first principal component explained $30.5 \%$ of the total variance, whereas other PCs explained $28.1 \%, 14.3 \%$ and $8.0 \%$, respectively. The highest contribution to the first principal component PC1 exhibited Fe, $\mathrm{K}, \mathrm{Mg}$ and $\mathrm{Na}$, whereas the highest contribution to PC2 exhibited $\mathrm{Co}, \mathrm{Cu}, \mathrm{Mn}$ and $\mathrm{Zn}$. $\mathrm{Ba}, \mathrm{Ca}, \mathrm{Pb}$ and $\mathrm{Sr}$ gave their variances to PC3, and $\mathrm{Ni}$ and $\mathrm{Se}$ to PC4. The results of PCA are convergent with the results of CA. Statistical tests revealed the existence of significant differences between the values of three of the four principal components among the experimental groups (Table 4).

Table 3. Loadings, eigenvalues and variances of the significant principal components.

\begin{tabular}{ccccc}
\hline & PC1 & PC2 & PC3 & PC4 \\
\hline $\mathrm{Fe}$ & $\mathbf{0 . 8 8 5 6}$ & -0.2961 & 0.0761 & -0.2164 \\
$\mathrm{~K}$ & $\mathbf{0 . 7 1 4 5}$ & -0.6576 & -0.0385 & -0.1210 \\
$\mathrm{Mg}$ & $\mathbf{0 . 7 1 4 0}$ & -0.6606 & 0.0144 & 0.0365 \\
$\mathrm{Na}$ & $\mathbf{0 . 8 3 3 8}$ & -0.3819 & 0.1516 & -0.1083 \\
$\mathrm{Ba}$ & -0.0009 & -0.2755 & $\mathbf{0 . 6 4 7 6}$ & 0.4499 \\
$\mathrm{Ca}$ & -0.4113 & -0.4392 & $\mathbf{0 . 6 7 5 0}$ & 0.0232 \\
$\mathrm{Co}$ & -0.0576 & $-\mathbf{0 . 7 7 7 0}$ & -0.4085 & -0.4381 \\
$\mathrm{Cr}$ & -0.5076 & 0.1352 & -0.0874 & 0.2119 \\
$\mathrm{Cu}$ & -0.3889 & $-\mathbf{0 . 7 2 5 4}$ & -0.3506 & 0.0714 \\
$\mathrm{Mn}$ & -0.5605 & $-\mathbf{0 . 7 3 8 4}$ & -0.1584 & $\mathbf{0 . 4 5 9 6}$ \\
$\mathrm{Ni}$ & -0.6278 & -0.0261 & 0.3796 & -0.3285 \\
$\mathrm{~Pb}$ & 0.1769 & -0.5156 & $\mathbf{0 . 6 0 4 1}$ & $\mathbf{0 . 5 2 7 5}$ \\
$\mathrm{Se}$ & -0.3400 & -0.5530 & -0.3038 & 0.2025 \\
$\mathrm{Sr}$ & -0.5850 & -0.3041 & $\mathbf{0 . 5 0 7 8}$ & 0.0885 \\
$\mathrm{Zn}$ & -0.5447 & $-\mathbf{0 . 6 9 4 1}$ & -0.2456 & 1.19 \\
\hline Eigenvalue & 4.58 & 4.21 & 2.15 & 7.96 \\
Variance $(\%)$ & 30.5 & 28.1 & 14.3 & \\
Cumulative (\%) & & & & \\
\hline
\end{tabular}

The most significant loadings are boldfaced.

Table 4. The comparison of experimental groups regarding identified factors.

\begin{tabular}{cccccc}
\hline & SAF & SAFplus & CLA & CLAplus & $p$ Value \\
\hline PC1 & $0.63 \pm 0.50^{\mathrm{b}}$ & $-1.10 \pm 0.36^{\mathrm{a}}$ & $0.58 \pm 0.53^{\mathrm{b}}$ & $-0.04 \pm 1.25^{\mathrm{ab}}$ & 0.0092 \\
PC2 & $-0.76 \pm 1.56^{\mathrm{a}}$ & $0.38 \pm 0.50^{\mathrm{ab}}$ & $-0.10 \pm 0.49^{\mathrm{ab}}$ & $0.52 \pm 0.42^{\mathrm{b}}$ & 0.0159 \\
PC3 & $0.10 \pm 1.02^{\mathrm{a}}$ & $-0.50 \pm 0.92$ & $0.06 \pm 1.34$ & $0.38 \pm 0.56$ & 0.2668 \\
PC4 & $0.52 \pm 1.18^{\mathrm{a}}$ & $0.33 \pm 0.75^{\mathrm{ab}}$ & $0.02 \pm 0.57^{\mathrm{ab}}$ & $-0.98 \pm 0.77^{\mathrm{b}}$ & 0.0229
\end{tabular}

Data are presented as mean \pm SD. ab-values with different superscripts in rows significantly differ at $p$ value $\leq 0.05$ multiple comparison test. SAF group-animals receiving safflower oil; SAFplus group-animals receiving safflower oil treated with DMBA; CLA group-group of animals receiving Bio-C.L.A.; CLAplus groupgroup of animals receiving Bio-C.L.A. treated with DMBA. 
Biplot PC1 $\times$ PC2 (Figure 3a) confirms that $\mathrm{Na}, \mathrm{Fe}, \mathrm{Mg}$ and $\mathrm{K}$ were positively correlated with the PC1 axis. Moreover, a strong positive correlation was revealed between $\mathrm{Na}$ and $\mathrm{Fe}$ as well as $\mathrm{Mg}$ and $\mathrm{K}$. Zn, Mn, $\mathrm{Cu}$ and Co were strongly negatively correlated with the PC2 axis. However, a strong positive correlation was observed between $\mathrm{Zn}$ and $\mathrm{Mn}$, and a little bit weaker positive correlation was shown for these two variables and $\mathrm{Cu}$ content. Individuals from SAF group were located in the positive values of PC1, which indicated high levels of $\mathrm{Na}, \mathrm{Fe}, \mathrm{Mg}$ and $\mathrm{K}$, whereas SAFplus individuals were located in negative values of PC1 and were characterized by the lowest levels of these elements. PC1 is mainly responsible for the discrimination of SAF from SAFplus, whereas PC2 and PC4 are responsible for the separation of CLAplus from SAF. Complete distinction of all four dietary groups was not achieved by using PCA.
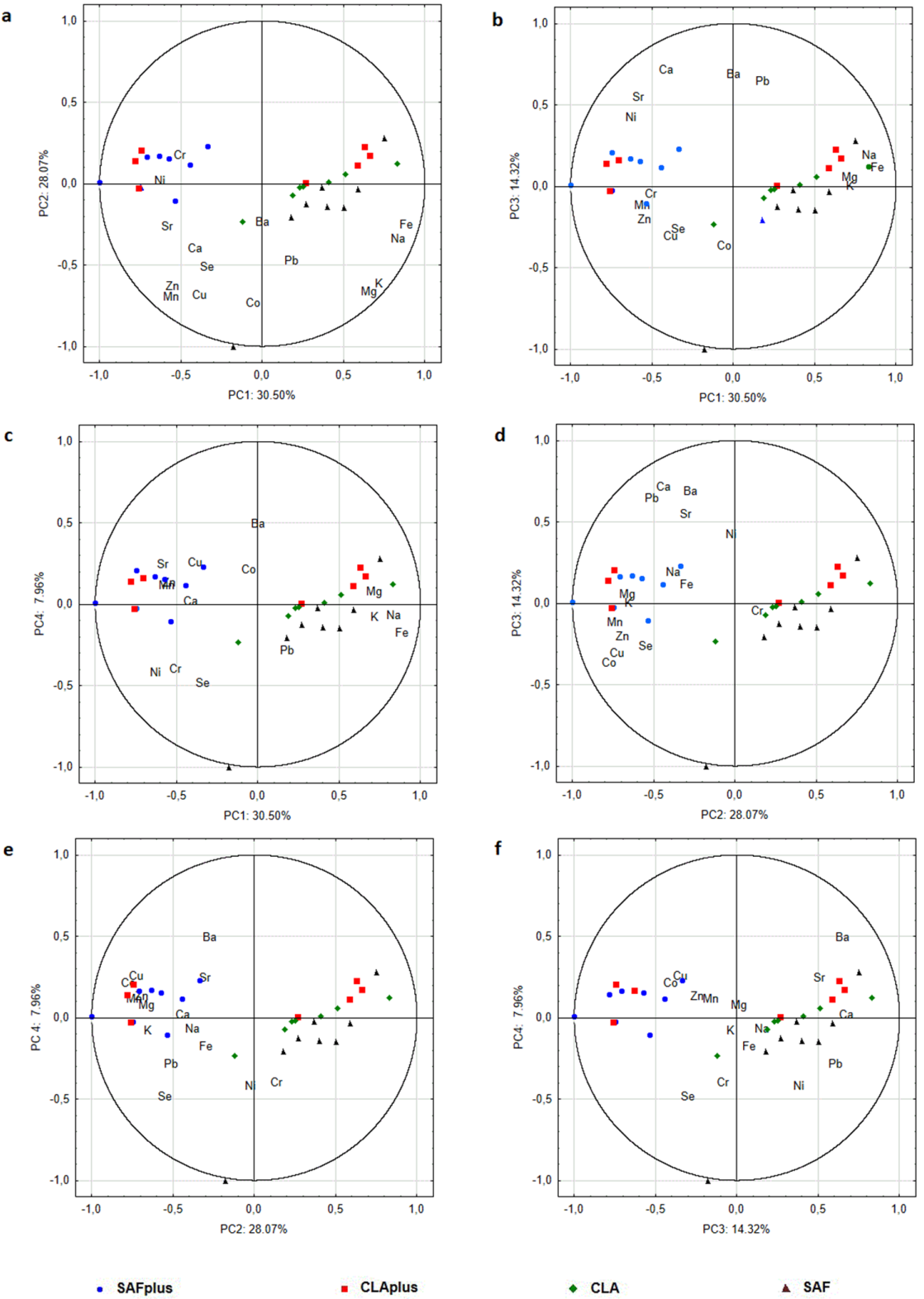

Figure 3. Biplots of minerals content in the myocardium of rats of experimental groups: (a) PC1 $\times$ PC2, (b) PC1 $\times$ PC3, (c) PC1 $\times$ PC4, (d) PC2 $\times$ PC3, (e) PC2 $\times$ PC4 and (f) PC3 $\times$ PC4. $\mathrm{SAF}$ group —animals receiving safflower oil; SAFplus group-animals receiving safflower oil treated with DMBA; CLA group—group of animals receiving Bio-C.L.A.; CLAplus group—group of animals receiving Bio-C.L.A. treated with DMBA. 
In the next step, LDA was used to obtain appropriate classification rules for the examined myocardium samples obtained from different experimental groups. Relevant discriminant functions were calculated in a stepwise progressive method. The percentage share of 15 minerals, which were detected in all examined myocardium samples, were included in the model. In the final model, eight variables were included, and four of them $(\mathrm{Mg}, \mathrm{Ni}, \mathrm{Mn}, \mathrm{Se})$ were significant in the model. All of them made a comparable contribution to overall discrimination. Applied canonical analysis allowed us to distinguish two statistically significant discriminant functions (DF). DF1 is the most significant function, as it explains $67.5 \%$ of the discriminatory power, whereas DF2 explains $27.2 \%$ of the discriminatory power (Table 5).

Table 5. Coefficients and average value of canonical variables included in the final model.

\begin{tabular}{ccc}
\hline \multicolumn{3}{c}{ Coeffcients of Canonical Variables } \\
\hline Variable (Discriminatory Power) & DF1 (67.5\%) & DF2 (27.2\%) \\
\hline $\mathrm{Mg}$ & 1.32041 & 0.95449 \\
$\mathrm{Cu}$ & -1.18252 & -0.30459 \\
$\mathrm{Ni}$ & -1.30381 & 1.44142 \\
$\mathrm{Mn}$ & 1.31693 & -1.66926 \\
$\mathrm{Se}$ & -0.89319 & 0.36417 \\
$\mathrm{~Pb}$ & 0.52141 & 0.37002 \\
$\mathrm{Co}$ & 0.65777 & 0.53331 \\
$\mathrm{Ca}$ & 0.31885 & -0.22727 \\
& Avarage value of canonical variables & \\
\hline SAF & 2.77985 & 0.06798 \\
SAFplus & -2.34742 & -2.06203 \\
$\mathrm{CLA}$ & 1.98196 & -0.02354 \\
CLAplus & -2.47616 & 2.30245 \\
\hline
\end{tabular}

The analysis of canonical mean variables indicated that DF1 had the greatest impact on the distinction of CLAplus and SAFplus samples from other samples, whereas DF2 seemed to distinguish CLAplus from SAFplus samples (Table 5). Graph analysis confirms the suggestion provided by the values of average canonic variables (Figure 4).

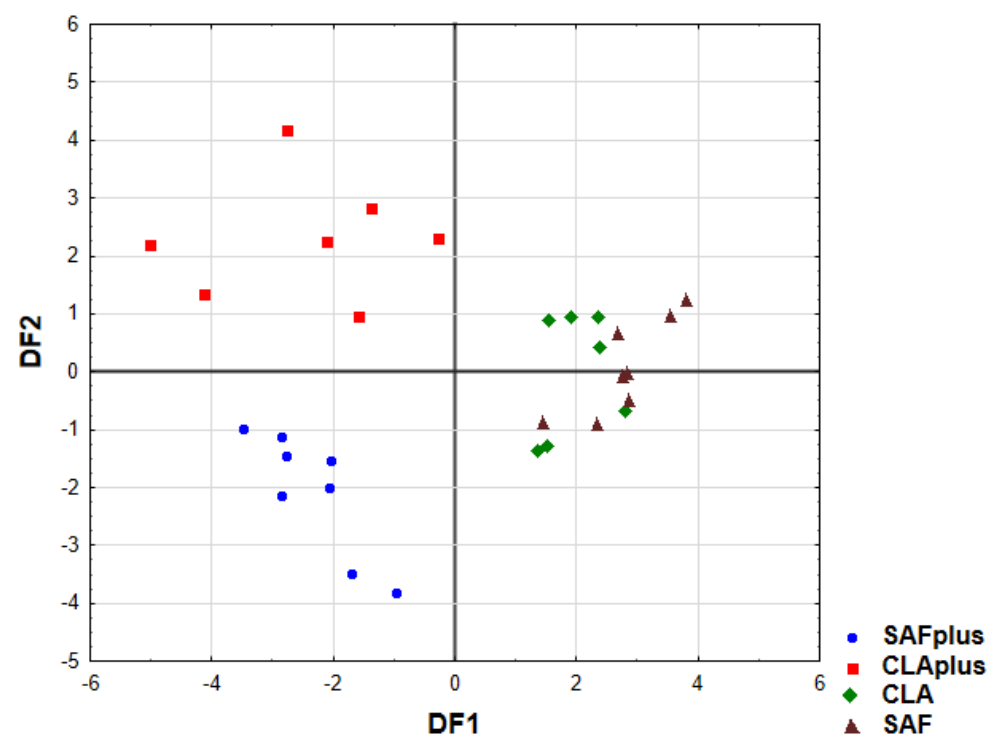

Figure 4. Scatter plot of canonical values for functions DF1 and DF2. SAF group-animals receiving safflower oil; SAFplus group-animals receiving safflower oil treated with DMBA; CLA groupgroup of animals receiving Bio-C.L.A.; CLAplus group-group of animals receiving Bio-C.L.A. treated with DMBA. 
A cross-validation of established LDA model was performed. Based on data concerning the content of the determined macro- and microelements, individuals were classified to experimental groups with the use of the discriminant functions distinguished in the first stage of LDA analysis. The calculated classification matrix indicated that the average classification efficiency based on the calculated functions was 93.3\% (Table 6). For individual groups, these coefficients were as follows: $100 \%$ for SAFplus and CLAplus, respectively, $87.5 \%$ for $\mathrm{SAF}$, and $85.7 \%$ for the CLA group.

Table 6. Classification results of the LDA presenting the percentage of predicted group membership for actual groups.

\begin{tabular}{cccccc}
\hline $\begin{array}{c}\text { Actual } \\
\text { Group }\end{array}$ & Correct & \multicolumn{4}{c}{ Predicted Group Membership } \\
Classification (\%) & SAF & SAFplus & CLA & CLAplus \\
\hline SAF & 87.5 & 0 & 0 & 1 & 7 \\
SAFplus & 100.0 & 8 & 0 & 0 & 0 \\
CLA & 85.7 & 0 & 0 & 6 & 1 \\
CLAplus & 100.0 & 0 & 7 & 0 & 0 \\
\hline$\Sigma$ & 93.3 & 8 & 7 & 7 & 8 \\
\hline
\end{tabular}

SAF group-animals receiving safflower oil; SAFplus group-animals receiving safflower oil treated with DMBA CLA group-group of animals receiving Bio-C.L.A.; CLAplus group—group of animals receiving Bio-C.L.A. treated with DMBA.

To give the most comprehensive view as possible, some dependences among the elements content and indices calculated based on fatty acids profile as well as heart weight were established. In the SAF group, the examined variables did not demonstrate any dependencies. Similarly, in the CLA group, only negative correlations between heart weight and $\mathrm{Ni}$ (Figure $5 \mathrm{a}$ ) and heart weight and the $\mathrm{Mg} / \mathrm{Ca}$ ratio (Figure $5 \mathrm{~b}$ ) were observed.

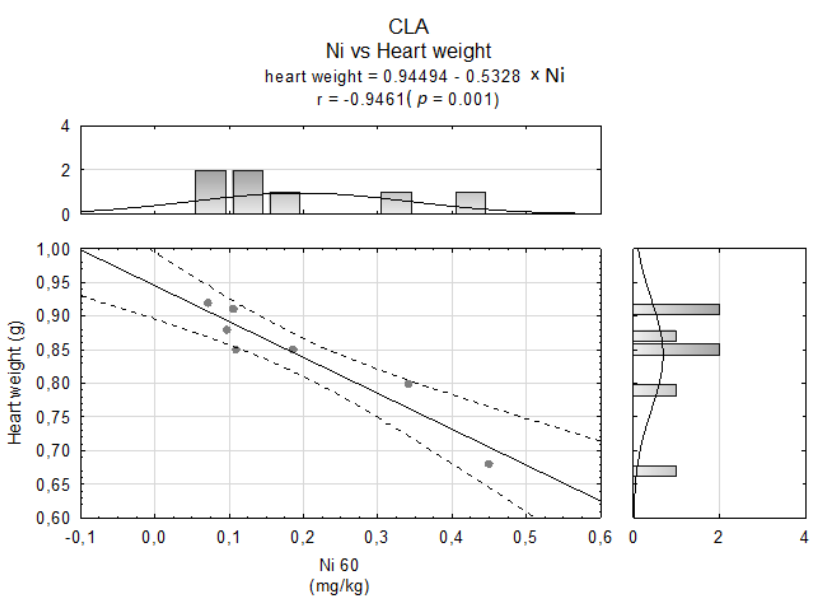

(a)

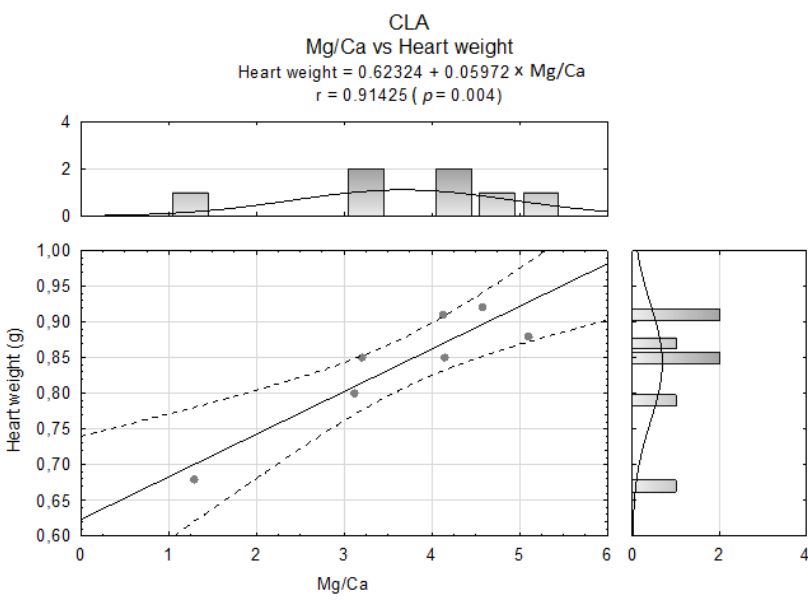

(b)

Figure 5. Correlations between (a) Ni content and heart weight and (b) $\mathrm{Mg} / \mathrm{Ca}$ ratio and heart weight in the CLA group.

In the two examined groups afflicted by breast cancer, some interesting correlations were established. In the SAFplus group, a significant positive correlation was observed between $\mathrm{Sr}$ and the peroxidability index (PI) in the hearts of animals (Figure 6a). Hence, in this group, the hypo/hypercholesterolemic index $(\mathrm{HH})$ was also negatively correlated with Se levels in cardiac tissue (Figure 6b). 


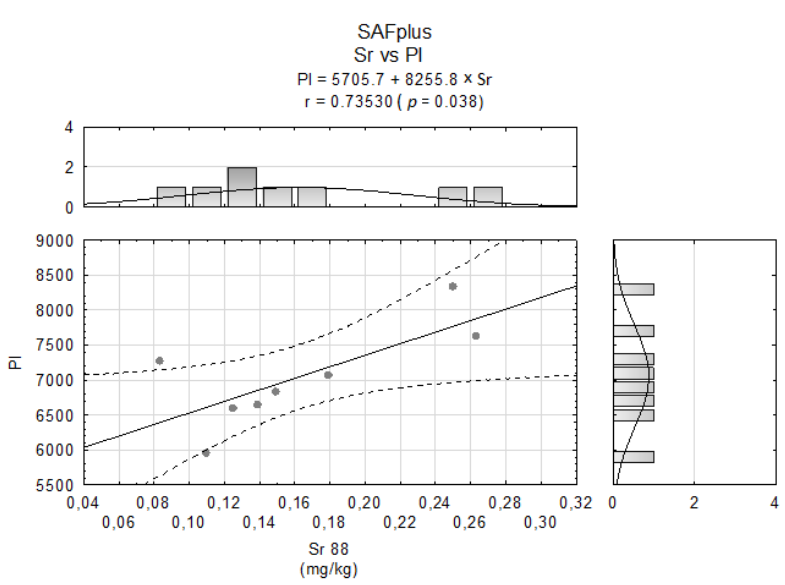

(a)

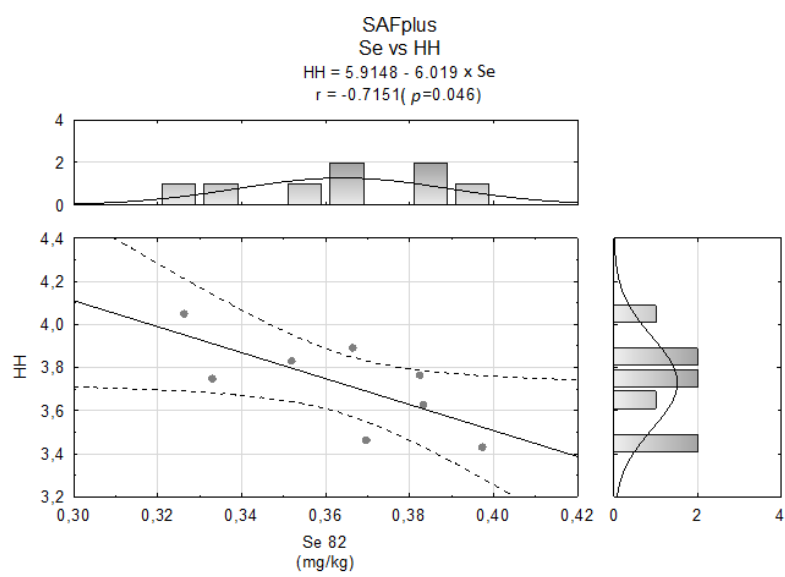

(b)

Figure 6. Correlations between (a) Sr content and peroxidability index and (b) Se content and HH index in the SAFplus group.

Se levels in the hearts of animals from the CLAplus group demonstrated a significant negative dependence with MDA content (Figure 7a) and positive correlations with the indices of atherogenicity (AI) and thrombogenicity (TI) (Figure 7b,c, respectively) established on the fatty acids profile of the hearts of rats [32]. Cr amounts of the hearts in the CLAplus group were negatively correlated with the $\mathrm{HH}$ index (Figure 7d).

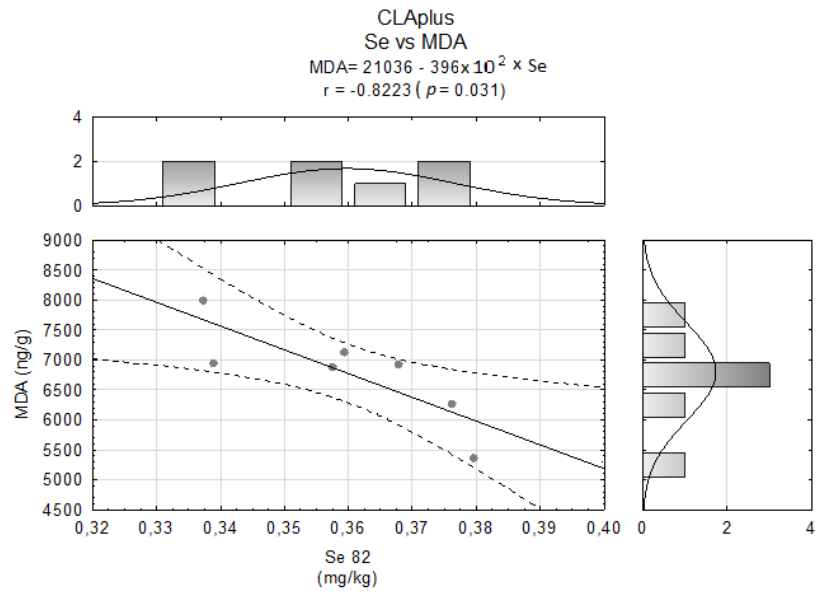

(a)

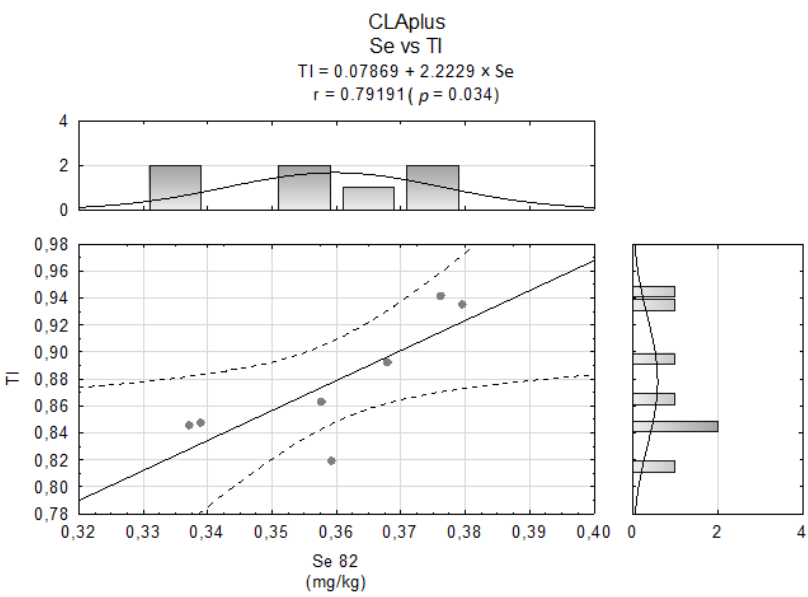

(c)

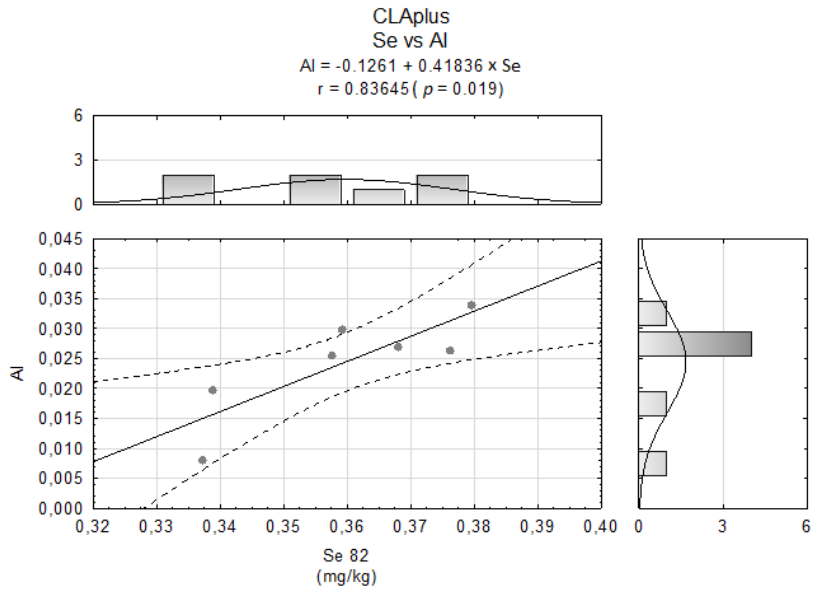

(b)

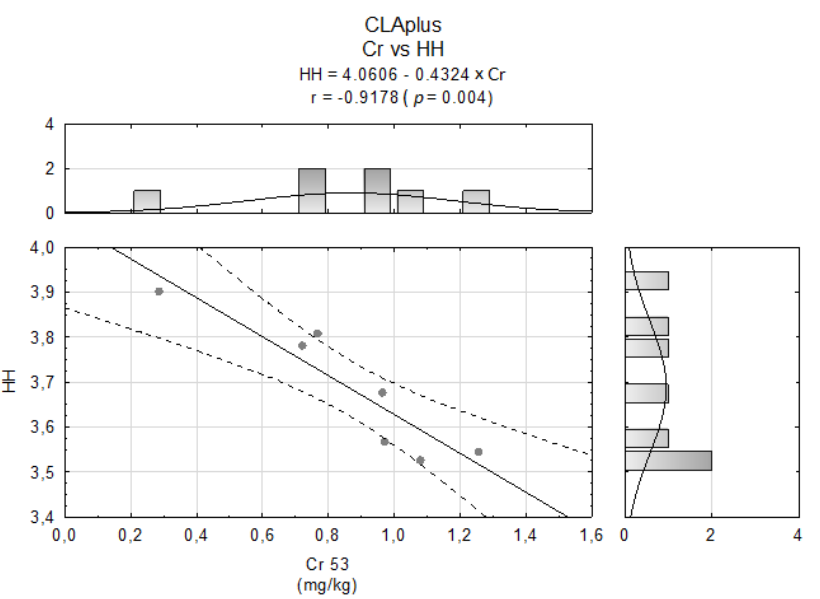

(d)

Figure 7. Correlations between (a) Se and malondialdehyde (MDA) content, (b) Se and AI, (c) Se and TI and (d) $\mathrm{Cr}$ and HH index in the CLAplus group. 


\section{Discussion}

Although cancer was previously considered to be one of the deadliest diseases, all applied medicinal procedures (e.g. screening, early detection or modern, targeted therapies) have made it a new "chronic" disease with an increasing number of survivors [33]. On the other hand, many chemotherapeutic agents, radiation therapies and novel, molecular therapies can negatively influence the cardiovascular system, causing cardiovascular mortality to be the principal cause of death 10 years after the diagnosis of breast cancer [34]. All these data coupled with the same risk factors shared by cancer and CVD contribute to the dynamic development of the cardio-oncology approach and to the investigation of different nutritional factors in cardio-oncological investigations. To the authors' best knowledge, this is the first attempt to assess the influence of dietary CLA supplementation on macro- and microelements content in the myocardium in a cardio-oncological animal model experiment.

The best established CLA influence on minerals is an increased intestinal Ca absorption, improved bone mass and reduced age-associated bone loss in mice [35]. Ca is also connected with CVD and cancer. In breast cancer tissue, microcalcifications are key diagnostically significant radiological features for localization of a malignancy [19], whereas in atherosclerosis, Ca depositions lead to the building up of plaque and consequently to narrowing or even blockage of the arteries [36,37]. In the present experiment, no differences in Ca levels in the myocardium of different experimental groups were detected, which indicates that CLA isomers' influence may be limited only to Ca deposition in bones or in the liver [36,38].

Beside $\mathrm{Ca}$, amounts of other macroelements were significantly reduced in the cardiac tissue of rats suffering from mammary tumors. Many studies have proven that those macroelements contribute to heart and muscle contractions, oxidative phosphorylation and the synthesis and activation of enzymatic systems [12]. Mg provides elasticity to prevent injury and acts with $\mathrm{Ca}$ to assist in muscle contraction and blood clotting and is thought to regulate blood pressure [39]. Deficiency of $\mathrm{Mg}$ contributes to tetany, Ca deficiency and the development of cardiovascular disease, diabetes mellitus and hypertension [39]. Significant decrease in serum concentration of $\mathrm{Mg}$ was observed in patients with breast cancer, especially those receiving chemotherapy [39]. The key role of decreased $\mathrm{Mg}$ concentration in pathogenesis of numerous disorders is linked with its capability to modulate intracellular processes via effects on signal transduction and antagonism of the effects of calcium $\left(\mathrm{Ca}^{2+}\right)$ as a second messenger [40]. Decrease of intracellular $\mathrm{Mg}$ concentration results in impaired ATP utilization and causes intracellular imbalance of $\mathrm{Ca}$ and $\mathrm{Na}$ [40]. Not only absolute concentrations of $\mathrm{Ca}$ and $\mathrm{Mg}$, but also their ratio is important for physiological regulation of different biochemical pathways [40]. A decreased $\mathrm{Mg} / \mathrm{Ca}$ ratio was detected in rats suffering from mammary tumors, especially those receiving SAF oil. Mg content in the myocardium also appeared to be one of significant factors responsible for distinguishing the experimental groups in the LDA model. It confirms its meaning for cardiac tissue conditions, especially in cancer-suffering individuals.

Exposure to trace elements and their tissue concentration is considered to be a modifiable risk factor of many diseases [6]. At the normal range, neither in deficiency nor in excess, trace elements help maintain body homeostasis. Otherwise, they may contribute to breast cancer development by influencing oxidative DNA damage and endocrine and immune system problems [18]. Especially Fe acts as a catalyst for the production of reactive oxygen species. In patients with breast cancer, estrogen of blood circulation facilitates releasing Fe for ferritin storage, and released Fe stimulates oxidative stress in the breast tissue [21]. However, Fe levels in the serum of breast cancer patients were significantly lower than in healthy individuals [18], while increased Fe levels were determined in the serum of patients with acute coronary syndromes, which may have resulted from the release of this elements from ischemic tissue. In the present study, significantly decreased levels of Fe were observed in the myocardium of the SAFplus group, and both diet and the coexisting cancerous process influenced the Fe level in heart tissue. 
$\mathrm{Cu}$, similar to $\mathrm{Fe}$, is considered an important factor in oxidative stress, which also participates in the pathogenesis of ischemic heart disease [41]. In the cell, $\mathrm{Cu}$ is mostly located in the cytosol, as a component of the superoxide dismutase, and in the mitochondria in proteins of the electron transfer chain, e.g., cytochromoxidase. Cardiac tissue, which is made up of cells with a high number of mitochondria, should be characterized by high $\mathrm{Cu}$ content [11]. In the case of Cu's relation with breast cancer, some authors observed significantly reduced $\mathrm{Cu}$ levels in the serum of breast cancer patients [23,37,42], whereas others quantified its increased concentration in comparison with healthy subjects $[6,7,18]$. Moreover, levels of $\mathrm{Cu}$ in the tumor area were significantly higher than its levels found in the non-tumor tissue [19]. These diversified results indicate not only great dynamics of redox processes during carcinogenesis, but also $\mathrm{Cu}$ involvement as a cofactor of these processes in the cell. $\mathrm{Cu}$ produces ROS through activation of several structural peroxidases [21]. It also induces apoptosis by p53-dependent and -independent pathways [23]. Decreased levels of $\mathrm{Cu}$ detected in the myocardium of CLA-supplemented rats may suggest an influence of CLA dietary intake with Cu levels, and also may confirm our previous observation concerning antioxidant properties of CLA isomers [32]. Strong interactions between $\mathrm{Cu}$ and $\mathrm{Fe}$ as well as between $\mathrm{Cu}$ and $\mathrm{Zn}$ exist, e.g., changes in dietary Fe contents influence $\mathrm{Zn}$ and $\mathrm{Cu}$ status in the body [43]. Although some differences in both Fe and $\mathrm{Cu}$ content in the myocardium were detected in present study and numerous experiments emphasize Zn involvement in both cancer $[7,19,21,23,37,42]$ and CVDs [7,11,14,41], no differences in $\mathrm{Zn}$ content were observed among experimental groups. It also reflected in lack of any differences in the $\mathrm{Cu} / \mathrm{Zn}$ ratio in the present study, although according to some authors, the $\mathrm{Cu} / \mathrm{Zn}$ ratio is higher in breast cancer patients $[6,7]$.

It was observed that the serum level of Se reflects its content in heart tissue, whereas for other elements, such a strong relationship was not found [11]. It is of great importance that changes in the Se level in serum were observed for different parameters of heart work and markers of CVDs, e.g., Se showed a positive correlation with ejection fraction in patients with cardiomyopathy or coronary heart disease, or patients with coronary heart disease had lower serum and erythrocyte Se concentration than healthy controls [11]. Additionally, erythrocytes of patients with heart failure were deficient in Se [15]. Lower levels of Se correlated well with the degree of myocardial damage as indicated by high levels of the prognostic markers [41]. Similar to the case of $\mathrm{Cu}$, the content of Se, which is part of the glutathione peroxidase system in the cytosol and mitochondria, is high in heart muscle cells [11]. In rats with hereditary stress-induced arterial hypertension, Se contents in the plasma and myocardium were higher than in normotensive animals, which was related to antioxidant properties of Se. Dietary Se is essential for the biosynthesis of Se enzymes (especially Se-cysteine-containing enzymes) and lipid antioxidants, and free Se-containing amino acids produce antioxidant effects, since they scavenge free radicals and are involved in non-radical degradation of lipid peroxides. In the rat myocardium, Se-containing peptides possessing antioxidant properties and catalyzing the indirect degradation of superoxide radicals were detected. All of these features make Se a potent cardioprotector [10]. Additionally, a strong inverse relationship has been found between serum Se concentration and risk of breast cancer, as Se exerts an anti-neoplastic effect as an important component of the antioxidant system (e.g., glutathione peroxidases containing Se-cysteine) [6]. Although no differences in Se content among experimental groups were observed in the present study, some interesting dependences among Se content and lipid peroxidation as well as indices of the fatty acids profile were observed. It is noteworthy to indicate that Se levels in cardiac tissue of the CLAplus group demonstrated a significant negative dependence with MDA content. This confirms antioxidant properties of Se and suggests antioxidant properties of CLA isomers [32] as well as an interaction between CLA and Se content in tissues, which we observed previously [44]. However positive correlations among Se and $\mathrm{AI}$ and TI reveal the strong need for further research concerning CLA and Se interactions as well as their health implication in both physiological and pathological conditions. It also confirms our strong belief that there is a great need of clear delimitation of drugs and 
dietary supplements and a great need of extensive investigations, as dietary supplements can exert opposite effects when given in physiological and pathological conditions.

$\mathrm{Mn}$ might share the similar anticarcinogenic properties as Fe and Se. Similar to $\mathrm{Mg}$, Se and Mn contents in the myocardium also appeared to be significant factors responsible for distinguishing the experimental groups in the LDA model. It confirms the great importance of Se and Mn levels for cardiac tissue conditions, especially in cancer-suffering individuals, especially due to their engagement in counteracting oxidative stress. $\mathrm{Mn}$ is a functional cofactor of various enzymes crucial for the various cellular activities, e.g., manganese superoxide dismutase (Mn-SOD) contains $\mathrm{Mn}$ in its active site, which has the cancer-fighting properties. High intracellular Mn can compensate for the loss of SOD and provide protection against oxidative stress. Mn disturbance might increase the risk of breast cancer through disrupting the balance of the oxidant/antioxidant system. Its lower levels were detected in breast cancer patients [20]. However, according to Choi et al., serum Mn levels were significantly higher $(p<0.05)$ in breast cancer patients than in controls patients [45]. Mn levels were decreased in the myocardium of rats from both CLA-supplemented groups, which indicates some dependencies between Mn and CLA, which need further examinations.

Numerous research studies have also revealed the involvement of some toxic elements in the cancerous process. $\mathrm{Cd}$ and $\mathrm{Ni}$ are classified in human carcinogen group 1 by the World Health Organization. Cd inhibits DNA synthesis, mismatch repair and enzyme function [23,46]. Ni compounds with the inhibition of intercellular connection could exhibit tumor-promoting ability through some mechanisms, such as immortalization of epithelial cells, generation of DNA protein cross-links, blockage of nucleotide-cutting repair and an increase in gene expression through DNA methylation [46]. Its serum concentration was significantly increased in breast cancer patients receiving chemotherapy [39]. In the present study, increased Ni content was detected in the myocardium of rats with mammary tumors, which confirms the previous results. Its content in cardiac tissue was also one of the significant factors responsible for distinguishing the experimental groups in the LDA model. Co is involved in DNA breaks and the inhibition of DNA repair and can be considered as a carcinogen. In physiological concentration, it acts in a cardioprotective manner, while its high dosage may cause cardiac failure [39]. Co content in the myocardium did not differ among experimental groups in the present study. Zheltova et al. found that $\mathrm{Mg}$ deficiency provoked changes of Co concentration in the most of studied tissues (in the heart, aorta, liver, kidneys, spleen and ovaries) and a 2-3 -old decrease of the Ni level in the heart, thyroid gland, spleen and uterus compared to the physiological level. They speculated that some $\mathrm{Mg}$-containing transporters may contribute to Co and $\mathrm{Ni}$ transport through biological membranes [40].

\section{Materials and Methods}

\subsection{Dietary Ingredients}

Laboratory fodder Labofeed H was purchased from "Morawski" Feed and Concentrates Production Plant (Kcynia, Poland). Commercially available Bio-C.L.A. dietary supplements in the form of gel capsules, containing an equimolar mixture of c9t11CLA and t10c12CLA, as well as safflower oil (SAF oil), used as substrate for Bio-C.L.A. production, were obtained free of charge by Pharma Nord (Warsaw, Poland). The composition of dietary ingredients in detail was published elsewhere [32].

\subsection{Animal Experiment}

This study was approved by the 2nd Local Ethical Committee on Animal Experiments at Medical University of Warsaw in terms of guiding principles on the care and use of laboratory animals (No. 34/2008). Virgin female Sprague-Dawley rats $(n=46,30$ days old) were obtained from the Division of Experimental Animals, Department of General and Experimental Pathology (Medical University of Warsaw, Warsaw, Poland). They were housed at $21^{\circ} \mathrm{C}$, in a $12 \mathrm{~h}$ light: $12 \mathrm{~h}$ dark cycle in a conventional animal room with 
constant access to the laboratory fodder and fresh drinking water ad libitum during the entire experiment. After 1 week of adaptation, the animals were randomly divided into 4 experimental groups. Detailed characteristics of the experimental groups are presented below.

SAF group $(n=8)$ and SAFplus group $(n=14)$-animals were fed laboratory fodder and received $0.15 \mathrm{ml}$ of SAF oil daily via gavage.

CLA group $(n=7)$ and CLAplus $(n=17)$-animals were fed laboratory fodder and were given $0.15 \mathrm{ml}$ of commercial dietary supplement daily (Bio-C.L.A.) via gavage. A detailed daily intake of dietary ingredients is given in Table 1.

Animals of each of the two "plus" groups intragastrically received in the 50th day of life a single dose (80 mg/kg body weight) of chemical carcinogen: 7,12-dimethylbenz[a]anthracene (DMBA, approx. 95\%; Sigma-Aldrich, Saint Louis, Missouri, USA), which was previously dissolved in SAF oil (SAFplus group) or in the oily filling pressed out from the capsule of commercial supplement (CLAplus group). Rats from SAF and CLA groups were not treated with DMBA. The dietary intervention lasted from the $37^{\text {th }}$ day of life of animals for the subsequent 21 weeks. Due to the unknown morbidity, DMBA-treated groups (SAFplus and CLAplus) were more numerous in comparison to groups without DMBA treatment (SAF and CLA) to ensure a statistically adequate number of rats with tumors.

Animals were monitored daily by the experienced veterinarian for specific signs of welfare and health disorders and weekly weighed and palpated for evaluation of tumors appearance. All the rats were decapitated in week 21 of the experiment and after exsanguination their hearts were excised, weighed (wet weight) and stored frozen in $-80{ }^{\circ} \mathrm{C}$ for further analyses. The experiment design as well as data concerning the hearts' mass was previously presented in detail in Figure 1 and in Table 2 [32] and they were not repeated in this manuscript to avoid self-plagiarism.

\subsection{ICP-MS Elements Determination}

The content of elements in hearts as well as in fodder and dietary supplements were determined according to Jagielska et al. [47]. Samples were dried for $24 \mathrm{~h}$ in $37^{\circ} \mathrm{C}$ in the drying oven SLN 240 (Pol-Eko, Wodzislaw Slaski, Poland), then weighed (100 mg-300 mg) and subjected to mineral digestion in the $69 \%$ aqueous solution of nitric acid (analytical grade, Merck, Darmstadt, Germany) $(1: 2, v / v)$ in glass tubes of a microwave ultraWave closed system with single reaction chamber technology (Milestone, Milan, Italy) for 15 min up to $200{ }^{\circ} \mathrm{C}$ and $10 \mathrm{~min}$ in $200^{\circ} \mathrm{C}$. After cooling down to the ambient temperature, digests were diluted in deionized water. For isotope-specific detection of selected elements $\left({ }^{11} \mathrm{~B}\right.$, ${ }^{23} \mathrm{Na},{ }^{24} \mathrm{Mg},{ }^{27} \mathrm{Al},{ }^{39} \mathrm{~K},{ }^{42} \mathrm{Ca},{ }^{57} \mathrm{Fe},{ }^{53} \mathrm{Cr},{ }^{55} \mathrm{Mn},{ }^{59} \mathrm{Co},{ }^{60} \mathrm{Ni},{ }^{63} \mathrm{Cu},{ }^{66} \mathrm{Zn},{ }^{82} \mathrm{Se},{ }^{88} \mathrm{Sr},{ }^{111} \mathrm{Cd},{ }^{138} \mathrm{Ba}$, $\left.{ }^{205} \mathrm{Tl},{ }^{208} \mathrm{~Pb}\right)$, a quadrupole mass spectrometer with inductively coupled plasma ionization, ICP-MS (Nexion 300D, Perkin Elmer Sciex, Waltham, Massachusetts, USA), equipped in quartz cyclonic spray chamber, Meinhard nebulizer and platinum skimmer cones, was used. The working conditions of the spectrometer were as follows: radio frequency plasma power $-1350 \mathrm{~W}$ and the constant nebulizer gas (Ar) flow $-0.9 \mathrm{dm}^{3} / \mathrm{min}$. Transient signals of the selected isotopes were monitored ( 1 reading $/ 5$ sweeps $/ 3$ replicates) with a dwell time of $100 \mathrm{~ms} /$ isotope. Quantitation was achieved by 5-point external calibration (concentration range: $1 \mu \mathrm{g} / \mathrm{dm}^{3}-100 \mu \mathrm{g} / \mathrm{dm}^{3}$ ). The limits of detection (LOD) and limit of quantitation (LOQ) were calculated for each element according to the IUPAC recommendation [48] together with the recoveries presented in the Table 7 . Recoveries were calculated as a ratio of received to certified values and presented as percentages. Samples and standards (ICP multi-element standard Merck VIII (Merck, Darmstadt, Germany), SRM 1577c Bovine Liver (NIST, USA)) were diluted with deionized water obtained by the Milli-Q system (Merck, Millipore, Darmstadt, Germany). 
Table 7. Values of limit of detection (LOD) ( $\mathrm{mg} / \mathrm{kg}$ ), limit of quantification (LOQ) (mg/kg) and recovery $(\%)$ of detected elements.

\begin{tabular}{cccc}
\hline & LOD & LOQ & Recovery \\
\hline $\mathrm{K}$ & 91.93 & 105.6 & 135 \\
$\mathrm{Mg}$ & 8.93 & 16.62 & 104 \\
$\mathrm{Na}$ & 644.4 & 829.2 & 130 \\
$\mathrm{Ca}$ & 21.47 & 26.06 & 90 \\
$\mathrm{Fe}$ & 70.51 & 82.71 & 80 \\
$\mathrm{Zn}$ & 0.202 & 0.325 & 85 \\
$\mathrm{Cu}$ & 0.063 & 0.090 & 90 \\
$\mathrm{Mn}$ & 0.023 & 0.028 & 101 \\
$\mathrm{Se}$ & 0.008 & 0.012 & 85 \\
$\mathrm{Co}$ & 0.001 & 0.001 & 103 \\
$\mathrm{Cr}$ & 0.035 & 0.043 & 400 \\
$\mathrm{Ni}$ & 0.024 & 0.033 & 114 \\
$\mathrm{Al}$ & 110.8 & 134.0 & - \\
$\mathrm{Sr}$ & 0.077 & 0.079 & - \\
$\mathrm{Ba}$ & 0.573 & 0.594 & 85 \\
$\mathrm{Cd}$ & 0.000 & 0.000 & 115 \\
$\mathrm{~Pb}$ & 0.046 & 0.051 & - \\
$\mathrm{B}$ & 234.4 & 270.6 & - \\
$\mathrm{Tl}$ & 0.009 & 0.013 & \\
\hline
\end{tabular}

\subsection{Malondialdehyde Analysis}

Samples of hearts were subjected to gentle alkaline saponification and derivatization with 2,4-dinitrophenylhydrazine (DNPH), followed by extraction with hexane and subjected to high-performance liquid chromatography analysis. The detailed methodology and results have been published previously [32].

\subsection{Indices Attributed to Calculation of Fatty Acids Properties}

Fatty acids content in cardiac tissue was quantified with capillary gas chromatography coupled with mass spectrometry (GC-MS). On the basis of the fatty acids content, indices attributed to the selected properties of fatty acids (index of atherogenicity-AI, index of thrombogenicity - TI, hypo/hypercholesterolemic index- $\mathrm{HH}$ ) were calculated. The detailed methodology and results have been published previously [32].

\subsection{Statistical Analysis}

The results, presented as means \pm standard deviation (SD), were analyzed with Statistica 13 software [49]. For the elimination of outstanding results, Dixon's Q test was used, while for the verification of normality of data distribution, the Shapiro-Wilk test was used. Only tumor-bearing rats from the SAFplus and CLAplus groups were considered in statistical analyses. Before statistical analyses, data with skew distribution were log-transformed. Multi-factor analysis of variance (ANOVA) was used to evaluate effects of diet (D), presence of mammary tumors $(M T)$ and their interactions $(D \times M T)$. When interaction occurred ( $p \leq 0.05$ ), the significances of differences among groups were established using the post hoc HSD Tukey test for uneven numbers for variables with normal distribution or the multiple comparison test for variables with skew distribution. $p \leq 0.05$ was considered significant.

In order to better understand the data trends, chemometric procedures were applied, where mineral levels in the myocardium were used as chemical descriptors to study a possible discrimination of the experimental groups. Because of missing data, the following elements-Al, B and Tl-were excluded from the analyses. Prior to all chemometric analyses, the original data were transformed into natural logarithms (log-transformed) and then auto-scaled (standardized) to avoid the dominant influence of macroelements on the prepared models. Only tumor-bearing rats from the SAFplus and CLAplus groups were 
considered in statistical analyses. Similarity analysis was performed by grouping of features and objects to prepare a heat map. Cluster analysis (CA) was performed to determine the similarity of the examined variables. Hence, CA was also performed to determine the similarity of the examined biological samples described by the set of variables. These analyses were carried out using the agglomeration method. Moreover, the Euclidean distance was used as the distance determination method and the Ward method was used as the agglomeration method. The application of more restrictive Sneath's criterion (33\%) was used for the dendrograms analysis and distinguishing clusters. Next, in order to provide a first evaluation of discriminating efficiency of mineral content in the myocardium, principal component analysis (PCA) was performed with standardized Varimax rotation. The factors were distinguished based on eigenvalues greater than 1 . The calculated factor values were compared between the groups using the Kruskal-Wallis test and multiple comparison test with the assumed significance level $p \leq 0.05$. Finally, in order to obtain appropriate classification rules for the myocardium samples based on the mineral levels, a linear discriminant analysis (LDA) was performed. In discriminant analysis, two essential steps are distinguished: In the first (learning) stage the classification rules are searched, creating of analytical model and the establishment of discriminant functions. In the second stage, which is called the classification (or validation) stage, based on rules defined in the learning stage, a set of objects, the belonging of which is unknown, is classified. In order to optimize LDA, relevant discriminant functions were calculated in a stepwise progressive method, with the adopted tolerance value $1-R^{2}=0.01$. The classification (validation) stage can be performed in two variants: (1) post hoc, when an object is classified to the group using the discriminant functions, which were established including this object (internal validation); or (2) a priori, when an object is classified to the group using the discriminant functions, which were established based on prior analysis of other objects (external validation). In our manuscript, due to the fact that no new set of objects (animals of experimental groups) was available, we performed the internal validation of our established LDA model in the post hoc variant. Based on data concerning the content of determined macro- and microelements, individuals were classified to experimental groups with the use of discriminant functions distinguished in the first stage of LDA analysis. The results of this cross-validation procedure, which describe the effectiveness of case (individuals) classification to experimental groups based on the previously created classification functions, was shown as the percentage of correct classification.

Hence, Spearman's coefficients were calculated for elements content and heart mass as well as for elements content and previously presented indices [32] attributed to selected properties of FAs, calculated on the basis of the FA profiles in cardiac tissue. $p$-value $\leq 0.05$ was considered significant.

\section{Conclusions}

The obtained results emphasize that dependencies among different elements in the body are complex and many different factors, such as diet, dietary supplements and physiological or pathological state, may influence them. All applied chemometric techniques, especially linear discriminant analysis, distinctly showed that the coexisting pathological process, to a greater extent than the applied diet supplementation with CLA or SAF, influences macro and microelements content in cardiac tissue. Induced changes include pronounced differences in macro- and microelements content in the myocardium of rats suffering from mammary tumors, which in turn may impinge on cardiac tissue condition and its susceptibility to injuries. It is of great importance, especially for oncological patients, to monitor the minerals content, especially taking into account possible cardiologic complications. The obtained results also confirmed the antioxidant properties of CLA and their relationship with Se deposition.

Author Contributions: Conceptualization, A.B., M.B. and M.C.; methodology, A.B., M.B., T.L., A.R., E.B. and M.C.; software, A.B. and T.L.; validation, M.B. and A.R.; formal analysis, A.B., E.B. and M.C.; investigation, A.B., M.B. and A.R.; resources, A.B., M.B. and E.B.; data curation, A.R.; writing- 
original draft preparation, A.B. and M.B.; writing—review and editing, A.B., M.B., T.L., A.R., E.B. and M.C.; visualization, A.B. and M.B.; supervision, M.C.; project administration, A.B.; funding acquisition, M.C. All authors have read and agreed to the published version of the manuscript.

Funding: This work was supported by the statutory funds of the Kielanowski Institute of Animal Physiology and Nutrition, Polish Academy of Sciences.

Institutional Review Board Statement: This study was approved by the 2nd Local Ethical Committee on Animal Experiments at Medical University of Warsaw in terms of guiding principles in care and use of laboratory animals (No. 34/2008).

Informed Consent Statement: Not applicable.

Data Availability Statement: Data available on request. The data presented in this study are available on request from the corresponding author. The data are not publicly available due to privacy restrictions of the collaborators.

Conflicts of Interest: The authors declare no conflict of interest.

Sample Availability: Samples of the PSO and BME or samples of biological material are not available from the authors.

\section{References}

1. WHO. Noncommunicable Diseases. Available online: https://www.who.int/news-room/fact-sheets/detail/noncommunicablediseases (accessed on 1 May 2021).

2. Kaptoge, S.; Pennells, L.; De Bacquer, D.; Cooney, M.T.; Kavousi, M.; Stevens, G.; Riley, L.M.; Savin, S.; Khan, T.; Altay, S.; et al. World Health Organization cardiovascular disease risk charts: Revised models to estimate risk in 21 global regions. Lancet Glob. Health 2019, 7, 1332-1345. [CrossRef]

3. WHO. Cancer. Available online: https://www.who.int/news-room/fact-sheets/detail/cancer (accessed on 1 May 2021).

4. Ganatra, S.; Hayek, S.S. Cardio-Oncology for GenNext: A Missing Piece of the Training Puzzle. J. Am. Coll. Cardiol. 2018, 71, 2977-2981. [CrossRef] [PubMed]

5. Ghosh, A.K.; Walker, J.M. Cardio-Oncology-A new subspecialty with collaboration at its heart. Indian Heart J. 2017, 69, 556-562. [CrossRef] [PubMed]

6. Adeoti, M.L.; Akanni, O.E.; Agodirin, O. Trace elements; Copper, zinc and selenium, in breast cancer afflicted female patients in LAUTECH Osogbo, Nigeria. Indian J. Cancer 2015, 25, 106-109. [CrossRef]

7. Okamoto, N.; Mikami, H.; Nakamura, Y.; Kusakabe, M.; Yamamoto, N.; Takiguchi, N.; Nabeya, Y.; Soda, H.; Fukasawa, S.; Kishida, T.; et al. A Nobel Multivariate Index for Cancer Risk Detection Based On the Serum Trace Elements: Metallo-Balance Method Abstract. J. Cancer Epidemiol. Prev. 2020, 5, 1-9.

8. Topaz, O. Myocardial calcifications in neonates and infants: A unique tissue reaction. South. Med. J. 1991, 84, 891-895. [CrossRef]

9. Mangialardo, S.; Cottignoli, V.; Cavarretta, E.; Salvador, L.; Postorino, P.; Maras, A. Pathological biominerals: Raman and infrared studies of bioapatite deposits in human heart valves. Appl. Spectrosc. 2012, 66, 1121-1127. [CrossRef] [PubMed]

10. Yakobson, G.S.; Antonov, A.R.; Golovatyuk, A.V.; Markel', A.L.; Yakobson, M.G. Selenium content and blood antioxidant activity in rats with hereditary arterial hypertension during experimental myocardial infarction. Bull. Exp. Biol. Med. 2001, 132, 641-643. [CrossRef]

11. Oster, O.; Dahm, M.; Oeler, H. Element concentrations (selenium, copper, zinc, iron, magnesium, potassium, phosphorous) in heart tissue of patients with coronary heart disease correlated with physiological parameters of the heart. Eur. Heart J. 1993, 14, 770-774. [CrossRef]

12. Suo, Y.; Wang, H.; Zhang, B. Effects of hypoxia on contents of essential elements in pika and rat heart. Biol. Trace Elem. Res. 2005, 103, 147-153. [CrossRef]

13. Ilbäck, N.G.; Fohlman, J.; Friman, G. Effects of selenium supplementation on virus-induced inflammatory heart disease. Biol. Trace Elem. Res. 1998, 63, 51-66. [CrossRef]

14. Rossi, L.; Ciriolo, M.R.; De Martino, A.; Giorgi, M.; G, R. Diferential decrease of copper content and of copper binding to superoxide dismutase in liver, heart and brain of copper-deficient rats. Biochem. Biophys. Res. Commun. 1994, 203, 1028-1034. [CrossRef]

15. de Lima, L.F.; Barbosa, F.; Simões, M.V.; Navarro, A.M. Heart failure, micronutrient profile, and its connection with thyroid dysfunction and nutritional status. Clin. Nutr. 2019, 38, 800-805. [CrossRef]

16. Oliveiros, L.; Vega, V.; Anzulovich, A.C.; Ramirez, D.; Gimenez, M.S. Vitamin A deficiency modifies antioxidant defense and essential element contents in rat heart. Nutr. Res. 2000, 20, 1139-1150. [CrossRef]

17. Hrdina, R.; Geršl, V.; Vávrová, J.; Holečková, M.; Palička, V.; Voglová, J.; Mazurové, Y.; Bajgar, J. Myocardial elements content and cardiac function after repeated i.v. administration of DMPS in rabbits. Hum. Exp. Toxicol. 1998, 17, 221-224. [CrossRef] [PubMed]

18. Ding, X.; Jiang, M.; Jing, H.; Sheng, W. Analysis of serum levels of 15 trace elements in breast cancer patients in Shandong. Environ. Sci. Pollut. Res. 2015, 22, 7930-7935. [CrossRef] [PubMed] 
19. Gonzales de Vega, R.; Fernandez-Sanchez, M.L.; Pisonero, J.; Eiro, N.; Vizoso, F.J.; Sanz-Medel, A. Quantitative bioimaging of Ca, $\mathrm{Fe}, \mathrm{Cu}$ and $\mathrm{Zn}$ in breast cancer tissues by LA-ICP-MS. J. Anal. At. Spectrom. 2017, 32, 671-677. [CrossRef]

20. Shen, F.; Cai, W.; Li, J.; Feng, Z.; Cao, J.; Xu, B. The association between deficient manganese levels and breast cancer: A meta-analysis. Int. J. Clin. Exp. Med. 2015, 8, 3671-3680.

21. Ahmadi, N.; Mahjoub, S.; Hosseini, R.H.; TaherKhani, M.; Moslemi, D. Alterations in serum levels of trace element in patients with breast cancer before and after chemotherapy. Casp. J. Intern. Med. 2018, 9, 134-139.

22. Naidu, B.G.; Naga, S.S.G.J.; Sarita, R.P. PIXE analysis of blood serum of breast cancer patients undergoing successive chemotherapy. J. Radioanal. Nucl. Chem. 2020, 323, 1307-1316. [CrossRef]

23. Arooj, B.; Ahmed, S.; Saleem, M.; Khurshid, R.; Zia, M. Serum Trace elements in diagnosis of breast malignancy. J. Ayub. Med. Coll. Abbottabad 2012, 24, 62-64.

24. Białek, A.; Tokarz, A. Sprzężone dieny kwasu linolowego jako potencjalny czynnik prewencyjny w profilaktyce nowotworów piersi. Postepy Hig. Med. Dosw. 2013, 67, 6-14. [CrossRef]

25. Białek, A.; Zagrodzki, P.; Tokarz, A. Chemometric analysis of the interactions among different parameters describing health conditions, breast cancer risk and fatty acids profile in serum of rats supplemented with conjugated linoleic acids. Prostaglandins Leukot. Essent. Fat. Acids 2016, 106, 1-10. [CrossRef] [PubMed]

26. Białek, A.; Tokarz, A.; Zagrodzki, P. Conjugated Linoleic Acids (CLA) decrease the breast cancer risk in DMBA-treated rats. Acta Pol. Pharm. Drug Res. 2015, 72, 1163-1176.

27. Stawarska, A.; Białek, A.; Stanimirova, I.; Stawarski, T.; Tokarz, A. The effect of Conjugated Linoleic Acids (CLA) supplementation on the activity of enzymes participating in the formation of arachidonic acid in liver microsomes of rats - Probable mechanism of CLA anticancer activity. Nutr. Cancer 2015, 67, 145-155. [CrossRef]

28. Białek, A.; Jelińska, M.; Tokarz, A. Influence of maternal diet enrichment with conjugated linoleic acids on lipoxygenase metabolites of polyunsaturated fatty acids in serum of their offspring with 7,12-dimethylbenz[a]anthracene induced mammary tumors. Prostaglandins Other Lipid Mediat. 2015, 116, 10-18. [CrossRef]

29. Białek, A.; Tokarz, A.; Dudek, A.; Kazimierska, W.; Bielecki, W. Influence of diet enriched with conjugated linoleic acids on their distribution in tissues of rats with DMBA induced tumors. Lipids Health Dis. 2010, 9, 1-9. [CrossRef] [PubMed]

30. Białek, A.; Tokarz, A.; Zagrodzki, P. Conjugated linoleic acids in diet of female rats inhibit the breast cancer formation in their offspring. J. Food Nutr. Res. 2014, 53, 39-50.

31. Jelińska, M.; Białek, A.; Mojska, H.; Gielecińska, I.; Tokarz, A. Effect of conjugated linoleic acid mixture supplemented daily after carcinogen application on linoleic and arachidonic acid metabolites in rat serum and induced tumours. Biochim. Biophys. Acta Mol. Basis Dis. 2014, 1842, 2230-2236. [CrossRef] [PubMed]

32. Białek, M.; Białek, A.; Czauderna, M. Conjugated Linoleic Acid Isomers Affect Profile of Lipid Compounds and Intensity of Their Oxidation in Heart of Rats with Chemically-Induced Mammary Tumors-Preliminary Study. Nutrients 2019, 11, 2032. [CrossRef] [PubMed]

33. Pituskin, E.; Paterson, I.; Cox-Kennett, N.; Rothe, D.; Perri, M.; Becher, H. The Role of Cardio-Oncology in the Interprofessional Care of Adult Patients Receiving Cancer Therapy. Semin. Oncol. Nurs. 2017, 33, 384-392. [CrossRef]

34. Cubbon, R.M.; Lyon, A.R. Cardio-oncology: Concepts and practice. Indian Heart J. 2016, 68, S77-S85. [CrossRef]

35. Park, Y.; Terk, M.; Park, Y. Interaction between dietary conjugated linoleic acid and calcium supplementation affecting bone and fat mass. J. Bone Miner. Metab. 2011, 29, 268-278. [CrossRef]

36. Czauderna, M.; Kowalczyk, J.; Bulska, E.; Boldižarova, K.; Niedźwiedzka, K.M.; Ruszczyńska, A.; Leng, L. Effect of dietary CLA isomers on selenium, zinc, copper, chromium, magnesium and calcium levels in rat liver. J. Anim. Feed Sci. 2005, 14, 529-532. [CrossRef]

37. Saleh, F.; Behbehani, A.; Asfar, S.; Ghada, I.; Khan, I. Abnormal Blood Levels of Trace Elements and Metals, DNA Damage, and Breast Cancer in the State of Kuwait Abnormal Blood Levels of Trace Elements and Metals, DNA Damage, and Breast Cancer in the State of Kuwait. Biol. Trace Elem. Res. 2011, 141, 96-109. [CrossRef]

38. Czauderna, M.; Kowalczyk, J.; Korniluk, K. Effect of dietary conjugated linoleic acid and selenized yeast on the concentration of fatty acids and minerals in rats. Arch. Anim. Nutr. 2007, 61, 135-150. [CrossRef] [PubMed]

39. Alta'ee, A.H.; Ewadh, M.J.; Kamil, Z.H. Role of Some Trace Elements in Breast Cancer Receiving Chemotherapy. Int. J. PharmTech Res. 2016, 9, 381-386.

40. Zheltova, A.A.; Kharitonova, M.V.; Iezhitsa, I.N.; Serebryansky, E.P.; Evsyukov, O.Y.; Spasov, A.A.; Skalny, A.V. Low magnesium diet alters distribution of macroelements and trace elements in tissues and organs of female rats. J. Trace Elem. Med. Biol. 2017, 39, 36-42. [CrossRef] [PubMed]

41. Altekin, E.; Coker, C.; Sisman, A.R.; Onvural, B.; Kuralay, F.; Kirimli, O. The relationship between trace elements and cardiac markers in acute coronary syndromes. J. Trace Elem. Med. Biol. 2005, 18, 235-242. [CrossRef] [PubMed]

42. Cabre, N.; Luciano-Mateo, F.; Arenas, M.; Nadal, M.; Baiges-Gaya, G.; Hernandez-Aguilera, A.; Fort-Gallifa, I.; Rodríguez, E.; Riu, F.; Camps, J.; et al. Trace element concentrations in breast cancer patients. Breast 2018, 42, 142-149. [CrossRef]

43. Suliburska, J. The impact of iron content in a diet high in fat, fructose, and salt on metabolic state and mineral status of rats. $J$. Physiol. Biochem. 2014, 70, 27-32. [CrossRef] 
44. Czauderna, M.; Białek, M.; Białek, A.; Śliwiński, B.; Brzóska, F. Chemical Form of Dietary Selenium Affects the Fatty Acids Profile and Oxidative Stability of Muscles of Broilers Supplemented with Lycopene and Oils. Eur. J. Lipid Sci. Technol. 2020, 122, 1900132. [CrossRef]

45. Choi, R.; Kim, M.-J.; Sohn, I.; Kim, S.; Kim, I.; Ryu, J.M.; Choi, H.J.; Kim, J.; Lee, S.K.; Yu, J.; et al. Serum Trace Elements and Their Associations with Cancer Patients. Nutrients 2018, 11, 37. [CrossRef]

46. Jouybari, L.; Naz, M.S.G.; Sanagoo, A.; Kiani, F.; Sayehmiri, F.; Sayehmiri, K.; Dehkordi, A.H. Toxic elements as biomarkers for breast cancer: A meta-analysis study. Cancer Manag. Res. 2018, 10, 69-79. [CrossRef] [PubMed]

47. Jagielska, A.; Ruszczyńska, A.; Wagner, B.; Bulska, E.; Skrajnowska, D.; Bobrowska-Korczak, B. ICP-MS analysis of diet supplementation influence on the elemental content of rat prostate gland. Mon. Fur Chem. 2019, 150, 1681-1690. [CrossRef]

48. Currie, L.A. Nomenclature in evaluation of analytical methods, including detect ion and quantification capabilities (IUPAC Recommendations 1995). Pure Appl. Chem. 1995, 67, 1699-1723. [CrossRef]

49. StaSoft Inc., StatSoft. Stat. Data Anal. Softw. Syst. 13 2016. Available online: https:/ /www.solvusoft.com/en/file-extensions/ software/statsoft-inc/ (accessed on 1 May 2021). 